So well equipped, he was appointed head of the Herolds Institute, Bermondsey, the first tanning school in London, which was opened in 1897. He remained here until 1909, when the school was transferred to the newly erected Leathersellers' Technical College, Tower Bridge Road, S.E.1, and he was principal of the College from that date until 1928, when he retired. He was elected a fellow of the Royal Institute of Chemistry in 1909 . On retirement, he continued in private practice as a consulting chemist to the leather industry, and was internationally known as an authority in this branch of chemical technology.

During the First World War, Dr. Parker was appointed a member of the Leather Supplies Committee at the War Office, and of the Allied Commission of Supplies, where his experience was placed freely at the disposal of the Government. For many years he was examiner in leather manufacture for the City and Guilds of London Institute. During the period 1914-18 he was also honorary secretary of the London Tanners' Federation and the United Tanners Federation. He was an honorary liveryman of the Worshipful Company of Leathersellers, and held the Order of Leopold (second class) and the Order of the Crown of Italy. In 1904 he was awarded the Silver Medal of the Royal Society of Arts for his investigations into the causes of the deterioration of bookbinding leathers.

Dr. Parker will be best remembered for his work in the formation and development of the International Association of Leather 'Trades' Chemists. The Association was formed in 1897, and at the time of his death he was one of the two remaining original members. That Association later developed into the International Society of Leather 'Trades' Chemists, with sections in many parts of the world (the Society was recently dissolved with the formation of autonomous societies and an intermational Union). He was the first secretary of the Association, and remained so until 1912, when he was elected president for the years 1912-14. He was awarded the Association's Gold Medal in 1912. After the First World War, he was elected president of the then newly formed Intermational Society for 1920-21, then treasurer for a period, and finally honorary secretary from 1929 until a year or so ago, when ill-health compelled him to forgo many of his activities. He was elected an honorary member of the Society in 1934 .

\section{Dr. Vaughan Cornish}

Dr. VAUGHAN CORNISH was a son of the vicarage, one of the most valuable groups in our national life, and his father's articles on Nature in south-eastern England in the late nineteenth century are still remembered for their intrinsic value and the beautiful form in which they were given. Dr. Cornish therefore had a good heritage of a kind he was to develop by his own efforts to understand, and to spread the understanding of, natural beauty. He was born in 1862 when his father was vicar of Debenham, Suffolk. After attending St. Paul's School, he studied chemistry at the University of Manchester, ultimately taking the D.Sc. degree and becoming director of technical education under the Hampshire County Council. In 1891 he married Ellen Agnes Provis and, with her, planned travel and research. His earlier researches, continued throughout life, were on waves -of water, snow and sand, on sea beaches, sand- banks, sand-dunes and snowdrifts. The Royal Geographical Society recognized his work by giving him the Gill Memorial Award in 1900. Earthquake waves were also studied in Jamaica in 1907, when both Dr. and Mrs. Cornish were injured; and the results of the inquiries were published in the Geographical Journal of 1912. In 1903, Dr. and Mrs. Cornish went around the world, making a special study of Japan, and later on they paid several visits to Panama to study the Canal while it was under construction. In 1911, Mrs. Cornish died and her husband some time afterwards published "The Travels of Ellen Cornish" as a tribute to her memory.

During the First World War, Dr. Cornish did a great deal of lecturing on strategic geographical questions to groups of officers in all branches of the Services, and thereby developed his interest and understanding of many matters of environmental conditioning of social and political life, the political side being more prominent in his mind and work. One of his best known books is "Great Capitals", with its analysis of the situations of capitals in their relations with the country concerned in each case. Dr. Cornish was a well-known and frequent contributor to the work of the British Association for the Advancement of Science, and in 1923 was president of Section $\mathrm{E}$ (Geography) of the Association. He was also a faithful friend of the Geographical Association and occupied its presidential chair. One remembers the distinguished figure wandering around at meetings looking for some fine piece of architecture, or some gem of natural scenery to be sketched and studied and discussed from an æesthetic rather than from a historical point of view. He gave much thought to the work of the Council for the Preservation of Rural England and wrote for it "The Scenery of England" (1932); but his most personal interest was in trying to use resthetics as a channel of approach to truth. "The Poetic Impression of Natural Scenery" (1931) is but the best known of his many efforts in this field. If one cannot point to any very definite doctrine of his concerning asthetics, we can appreciate, perhaps all the more, the spirit of the searcher after truth who had learned from a scientific training that truth is too great to need propagandist crutches.

Dr. Cornish's second wife was Miss Watson, who was the widow of Mr. E. A. Floyer. In his later years Dr. Cornish derived much pleasure from the inheritance of South Combe farm on which is Salcombe Hill, Devon. He gave this hill-top to the public and supported efforts to protect public amenities in Devon.

WE regret to announce the following deaths:

Prof. W. T. David, professor and head of the Engineering Departments of the University of Leeds, on May 22, aged sixty-two.

Mr. G. L. Overton, formerly a member of the staff of the Science Museum, London, on May 22, aged seventy-two.

Dr. G. H. Pethybridge, O.B.E., formerly mycologist to the Ministry of Agriculture and Fisheries and assistant director of the Ministry's Plant Pathology Laboratory, Harpenden, Herts, on May 23, aged seventy-six.

Mr. J. J. Shaw, C.B.E., who maintained his own seismological observatory at West Bromwich, on May 23, aged seventy-four. 